\title{
Women and the Development of hadith Literature
}

\section{UnSUNG Heroines}

The role of women as sources, and later as scholars, of hadith, managed to be significant as thankfully the more extreme currents of misogyny were widely rejected by the majority.

Around 12 women served as sources of 20 or more hadiths each, most notably Aisha, who is the fourth most-prolific source overall with over 2000 attributed to her (a total of over a thousand sources are recorded though only about 500 of these relayed more than a single hadith). ${ }^{1}$ As to women scholars of hadith and other Islamic "sciences", as they are referred to:

History records few scholarly enterprises, at least before modern times, in which women have played an important and active role side by side with men. The science of hadith forms an outstanding exception in this respect... .At every period in Muslim history, there lived numerous eminent women-traditionists [ hadith scholars], treated by their brethren with reverence and respect. Biographical notices on very large numbers of them are to be found in the biographical dictionaries [of hadith transmitters and scholars $]. .$.

${ }^{1}$ Siddiqi, Muhammad Zubayr. 1993. Hadith Literature: Its Origin, Development and Special Features. Cambridge, England: The Islamic Texts Society, 15-18.

(C) The Author(s) 2022

L. El-Ali, No Truth Without Beauty, Sustainable Development

Goals Series, https://doi.org/10.1007/978-3-030-83582-8_4 
..many.....excelled in delivering public lectures on hadith. These devout women came from the most diverse backgrounds, indicating that neither class nor gender were obstacles to rising through the ranks of Islamic scholarship. For example, Abida, who started life as a slave..... learnt a large number of hadiths with the teachers in Medina....It is said that she related ten thousand traditions [in Andalusia] on the authority of her Medinan teachers ..... Zaynab bint Sulayman (d. 759), by contrast, was a princess by birth...[she] acquired mastery of hadith, gained a reputation as one of the most distinguished women-traditionists of the time, and counted many important men among her pupils. ${ }^{2}$

Some women travelled widely in pursuit of hadith and are known to have delivered lectures at their destinations to students also travelling far and wide to hear them, including in gender-mixed classes. Nor did women restrict themselves to badith but some also excelled in theology, law, history and grammar. But references to women scholars in the biographical dictionaries of eminent people began to dwindle noticeably from the sixteenth century on, with the last woman scholar of top rank from pre-modern times said to be Shaykha Fatima al-Fudayliya (d. 1831), whose students would receive certificates from her and who founded a rich public library in Mecca. ${ }^{3}$

\section{REFLECTIONS}

I have heard my friend Amr Abdalla, as part of a course on Islam ${ }^{4}$ that he gives annually at the Wesley Theological Seminary in Washington, DC, opine that the rise of the Ottoman Islamic Empire marked by its expulsion in 1453 of the Byzantines from Constantinople combined with the subsequent expulsion of the last Muslims from Andalusia in 1492 gave rise to an increasingly militaristic approach by Muslim rulers. Indeed, at the height of its power in the sixteenth century, the Ottoman Empire reached south-eastern Europe and Western Asia/Caucasus and the Arab heartland, and remained a force to be reckoned with until its defeat four centuries later in World War I and its subsequent disbandment. Against this

${ }^{2}$ Ibid., 117-118.

${ }^{3}$ Ibid., 122-123.

${ }^{4}$ Amr Abdalla is Professor Emeritus of Peace and Conflict Studies at the University for Peace, Costa Rica. He has published articles and other works on Islamic perspectives to conflict resolution. 
backdrop, I can see how resources and the environment may have shifted towards outward preoccupations, whether of desire for power or survival, at the expense of scholarship and erudite pursuits in general.

Today, however, Islamic scholarship is back and I would say at its historic peak, at least qualitatively speaking. In an increasingly interconnected world where no one can live in isolation from other ideas or from questions about one's own inherited ones, Islamic scholars of all backgrounds, most of whom are Muslim either by birth or by choice as adults, have risen to the challenge, and we owe them all an enormous debt of gratitude. Many of these scholars, though not all, live in the West. And it is increasingly among these that we see a resurgence of women scholars of Islam, whether they are native Muslims (such as among the African American community), Muslim immigrants, descendants of Muslim immigrants, non-Muslim scholars of Islam, or recent arrivals to Islam: I never like to use the word "convert" because it implies that a person rejects whatever religion they came from to adopt Islam, whereas for many who take this step it is an act of adding (not subtracting) a dimension, one that comes in the form of adopting a message from yet another one of God's messengers.

The point is that we have all we need qualitatively today in terms of answers and guidance in these trying times. What remains is for us to make this top-quality information as accessible as possible, to as many people as possible.

Open Access This chapter is licensed under the terms of the Creative Commons Attribution 4.0 International License (http://creativecommons.org/licenses/ by $/ 4.0 /$ ), which permits use, sharing, adaptation, distribution and reproduction in any medium or format, as long as you give appropriate credit to the original author(s) and the source, provide a link to the Creative Commons licence and indicate if changes were made.

The images or other third party material in this chapter are included in the chapter's Creative Commons licence, unless indicated otherwise in a credit line to the material. If material is not included in the chapter's Creative Commons licence and your intended use is not permitted by statutory regulation or exceeds the permitted use, you will need to obtain permission directly from the copyright holder.

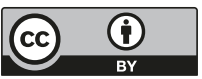

